\title{
A Review Paper on self-concept of school teachers in Government and Private Primary schools
}

\author{
Sunny Bansal \\ Research Scholar- Manav Rachna University, Faridabad
}

\begin{abstract}
Education is considered to be the best friend of any individual.It helps him to act rightly and understand the true meaning of life. Education is the foundation on which every successful nation is build. Success and progress of any nation is dependent on the educational foundation of people of country. The torch bearers of education are teacher's. In Indian culture, teachers have always been given the utmost respect. Teachers have been considered as the most powerful agents of social change. A successful teacher is the one who has passion to teach and is able to give instructions to students according to their individual needs

As teacher's are the most important link between students and education, the teacher's personality is the ideal for a child. The experiences of a teacher, inside and outside school, helps in evolving her personality. As teacher has to efficiently play many roles in school,it is very important that a teacher should have high and positive self-concept. Many studies have been completed on self-concept of teachers but still limited information is available on how to develop and maintain positive self-concepts amongst teachers so that they are successful in primary schools. This article is an attempt to get an insight on how self-concept is perceived and is different amongst teachers of private and govt primary schools.
\end{abstract}

key words: Self Concept, Teachers Self-Concept, Self-Efficiency, Literature Review

\section{INTRODUCTION}

Self-concept has been studied by many researchers in different fields like business, health and education,etc. Selfconcept is what an individual believes about himself/herself.It is a perception that an individual has about himself. It is concerned with how a person views himself socially,emotionally and physically.It is a kind of roadmap that an individual follows to understand oneself in various circumstances. An individual's self-concept is the image of a person in his own mind irrespective of what other people thinks of him.Understanding of one's self-image leads to clarity of self-identity, self-evaluation and self-ideal. Various terms like 'self-image', 'ego', 'self-perception' areconsidered synonymous with self-concept.Self-concept is considered to be the most dominating factor in a person's life as each and every individual works for self realization and self betterment and wants to avoid any such experience which lowers the one's self concept. After developing self concept, an individual takes charge of his own behaviour and conscience.

Since starting of 1900, self-concept with respect to teachers and their performance has been studied by psychologists and sociologists alike. Many researchers have determined that self-concept is a major determinant of teacher's performance in class. As students spend a lot of time with their teacher's in school and their quality of teaching directly effects the performance of students, it has become very important to understand and study about various factors that increases teacher's efficiency, self-concept being one of them. Self-concept has been considered an important factor to be focused on while getting trained for being a teacher and it has also been considered a major factor in identifying teaching behaviour and efficiency. Students in class of teacher who has positive self-concept and self-worth has been found to achieve and perform better than the students who are lead by teacher with low self-concept. Teachers with positive self-concept will be able to identify her strengths and weakness,able to come out of any difficult situation in classroom and beyond, and will be able to understand that all students have different feelings, different intellectual levels and needs and thus will be able to handle them and teach them accordingly. Thus, a positive self concept of a teacher will have a direct influence on student's learning and will enhance the quality of delivery of Education.

\section{Need of Study:}

Learning and imparting education has now become more compatible with the social and emotional needs of students and teachers. This has led to many educationist focusing on the relationship between self-concept and social-emotional teaching. Many teacher training programmes have now started focusing on social-emotional learning. Keeping in mind the attention that is now given to learn and teach social and emotional skills in schools by teachers, the study on selfconcept and its effect on teaching seems important to researcher. 


\section{International Advanced Research Journal in Science, Engineering and Technology}

Vol. 8, Issue 12, December 2021

DOI: $10.17148 /$ IARJSET.2021.81209

\section{OBJECTIVE:}

To analyze various research papers written on "Self-concept of Government and Private Primary Schools Teachers"

Analysis of the literature on Self concept of School Teachers in Government and Private Primary schools:

Review of literature is about studying the data which has already been published. It helps the researcher to conduct further research.Many previous researchers and their studies states that there is a positive relationship between positive self concept and effective teaching.

Piers and Harris(1964) defined self concept as" relatively stable set of attitudes reflecting both description and evaluation of one's own behaviour and attributes."They divided self concept into following dimensions:

1)Stable

2)Changing

3)Situational

4)Phenomenal

5)Internal

6)Normative

7)Absolute personal

8)Non-evaluative

9)Unidimensional

10)Multidimensional

Taneja(1988) during his research on relationship between creativity and self-concept of school teachers found out that there was a positive relationship between self-concept and vision of job security.Also, there was a positive relationship between self-concept and teacher's creativity in classroom.

Shah(1991)in his study states that an efficiency of teacher in classroom is effected byself-concept ,job satisfaction and job motivation. Positive the self concept is, more is the efficiency of teacher.

Agnihotri, A., (1999) stated that self-concept includes physical, social and academic perception of an individual. It includes an attitude of an individual towards his own self- worth and decisions taken by him in his life. Self-concept is made of an individual's judgement of his own strength, weaknesses, shortcomings and life experiences.

Wang (2000) stated that teacher's performance in classroom is greately effected by her self-concept.Self-concept of teacher will determine their teaching methods, their pedagogy in the classroom and their relationship with students. Teacher's self-concept and her performance in classroom has been found to have a positive relationship by many researchers.

Leary and Tangney(2003) described self-concept as "the set of processes that allows individuals to think about themselves." How an individual sees his own experiences and what they learn from it depends on their own understanding of self.

Marsh and craven (2006) stated that the teacher's self-concept is multidimensional and hierarchical in nature. At top of pyramid is general self-concept, which can further be divided into academic and non-academic self-concept. Nonacademic self concept is further divided into physical, social and emotional components. Physical component includes physical appearance. Social component includes connect with peers and emotional component includes the teacher's various emotional states. Academic self-concept is attributed to teacher's knowledge and her confidence in her particular subject.

Gayatri(2008) stated that self-concept during development of child is influenced by meeting. Other important persons like parents, teachers and elder siblings and many more. As students spend almost 8-9 hours in school, teachers have a profound impact on student's self-concept. Teacher's help a student to develop positive self-concept and it is only possible if teacher herself has a positive self-concept about herself.

Marsh and martin(2011)research on self concept and its effect on teaching as a profession revealed that both male and female teachers in primary schools had apositive self concept and it led to their better attitude towards teaching as a profession.

Mercer(2011) stated that teacher's play numerous roles in school like as a lecturer, as a link between school and parents, motivating students, as an evaluator of students performance and many more. As self-concept determines the performance of an individual in his/her career, then it can be considered as a vital factor that effects teacher's performance in classroom.

Devos et al (2012) described self concept with respect to teacher's as her perception of her own teaching effectiveness. They spoke about importance of the teacher's self-concept in many psychological variables concerned to 


\section{International Advanced Research Journal in Science, Engineering and Technology}

Vol. 8, Issue 12, December 2021

\section{DOI: $10.17148 /$ IARJSET.2021.81209}

teaching. They also focused on the importance of developing and using various teacher training programs focusing on developing positive self-concept.

Zlatkovic(2012) stated that self-concept effects the teacher's interest and motivation for teaching but is rarely considered in teacher's training programmes. He also stated that an individual's interest in any profession depends on the desire that person has for that profession. This desire can be dependent on many factors like talent, social status, personality etc which constitutes into self-concept.

Kumazawa(2013) in his study noted that self-concept plays a very important role in teacher's as well as student's achievementsand motivation in their respectiveareas. Self concept is considered to be one of the most important factor in humanlearning as how an individual perceive herself effects how we see our goals in future.

Yeung et al(2014) stated that the quality of teaching by any teacher in schooldepends on many factorswhich can be divided into internal and external factors.Internal factors include teachers ability, self-concept etc. whereas external factors include schoolsinfrastructure, access to technology and many more.

Tabassum\&Bibi(2014) stated that some of important characteristics of teacher'spersonality are that teachershould be warm-hearted rather than cold-hearted, should be responsible for her student'sbehaviour and performance and should be creative and come up with newideas/projects rather than normal routine. He further stated that all these characteristics are governed by a teacher's self-concept.

\section{CONCLUSION:}

1) Not much research has been done in the area of self concept with respect to school teachers but it is very important to note and address various characteristics that helps in developing positive self-concept amongst school teachers.

2) The results of various studies in this paper differs as their time period also differs,thus giving different results. Also, it is worth mentioning that teaching profession has undergone a vast shift in last three decades in India, after private schools were open. Infrastructure, salaries, Facilities, job security are better in private schools than government schools.

3) Literature talks about many different definitions of self-concept and its impact on teacher's performance in classroom. Many researchers have found out positive relationship between positive self concept and better teacher performance in classroom thus leading to better achievement and performance by students of that teacher.

4) Many researchers have given importance to a fact that a student is academically productive when he feels comfortable and safe in class, develops positive self concept about himself and is ready to face any situation. This ambience can only be created by a teacher who is effective, competent and has positive self-concept about herself.

\section{RECOMMENDATIONS}

Based on the study, researcher recommends following recommendations:

1) As it is apparent from research that how an individual feels about himself/ herself will have an effect on his/ her performance in his work,it becomes very important that teachers should be provided with proper and structured training and orientation about how to develop positive self-concept.

2) A committee of school including principal and management should interact with teachers on a regular basis, may be once a quarter, focusing on her strong and weak areas especially related to how she perceives herself. Teachers with low self-esteem can be given support of teacher counsellors and psychologists to improve their psychological wellbeing.

3) Every classroom has a mix of students,some are intelligent and some are weak,similarly, every school has teachers with different effectivity,competencies and with difference in how they perceive themselves.School should device such a mechanism that competition amongst these teachers should be eliminated.Teacher's, who are experienced and are well-adjusted should help teacher's, who needs counselling and motivation.

4) HR department of every school should also keep self-concept as a characteristic to look out for while hiring teachers. Teachers should be motivated regularly for the positive and committed attitude towards their profession.

\section{REFERENCES}

1) Agnihotri, A., Self-concept, anxiety, power value and socioeconomic status relationship. Indian Psychol. Rev., 35 (11-12): 19-23, 1999.

2) Devos,c.,dupriez,v.,\&paquay,l.’Does the social working environment predict beginning teacher's self-efficacy and feelings of depression?'Teaching and teacher education,28(2),206-217,2012.

3) Gayatri,A : "A Study of attitudes towards values and their practices in relation to certain personality factors among B.Ed students in Andhra Pradesh. Unpublished thesis in Education, S.V.University, Tirupati, 2008.

4) Kumazama,M.Gaps too large:Four novice EFL teachers self-concept and motivation.Teaching and Teacher Education,33,45-55, 2013.

5) Leary,M.R \&Tangney,J.P(Eds) . Handbook of self and identity, 2003. 
International Advanced Research Journal in Science, Engineering and Technology

Vol. 8, Issue 12, December 2021

\section{DOI: 10.17148/IARJSET.2021.81209}

6) Marsh,H.W.,\&Martin,A.J. Academic self-concept and academic achievement:Relations and causal ordering.British Journal of EducationalPsychology,81(1),59-77, 2011.

7) Marsh,h.w and craven,r.g,'reciprocal effects of self concept and performance from a multidimensional perspective.perspectivesonpsychological sciences.1(2),133-163,2006.

8) Mercer.S.Towards an understanding of language learner self-concept.NewYork.Springer, 2011

9) Piers, E. V., \& Harris, D. B. Age and other correlates of self-concept in children. Journal of Educational Psychology, 55(2), 91-95, 1964.

10) Shah,B.'Determinants as teacher effectiveness',University of Rohilkhand,Bareli,1991.

11) Taneja,S.R.' Relationship between creativity sense of humor and self-concept among secure and insecure female teachers trainees'Agra university,Agra, 1988 .

12) Tabassum,F.,Bibi,F.Comparison of professional self-esteem of public and private teachers. Journal of humanitiesand social science.1(18),2014.

13) Wang,g.j.'Exploring the relationship between teaching beliefs and teaching practices of teachers."Educational research \&information,8(2),8498,2000 .

14) Yeung,S.A,Craven.G.R., Kaur,Teacher's self-concept and valuing of learning :relations with teaching approaches and beliefs about students Asia-pacific journal of teacher education.42(2),305-320,2014.

15) Zlatkovic et al. Self-concept and teacher's professional roles.Prodia-Social and Behavirol Science,69, 377-384,2012. 